\author{
Michał Chaberek \\ Cardinal Stefan Wyszyński University in Warsaw \\ ORCID: 0000-0001-8071-537X
}

\title{
CMSWR versus LCWR: About the Crisis and the Renewal of Consecrated Female Life in the USA ${ }^{1}$
}

\begin{abstract}
The article discusses the history of reforms of American religious sisters initiated by Pius XII and concluded by a joint agreement between the LCWR and the Commissions of the Congregation for the Doctrine of the Faith. The article shows the character of the reforms undertaken before and after the Council and how two organizations representing American sisters were established. The continuous departure of the LCWR from the teaching of the Church is presented in opposition to the fidelity of the second organization with canonical status - CMSWR. The lack of vocations among the sisters gathered in the LCWR is a sign of mistakes in the reforms that were undertaken and politicization of the organization.
\end{abstract}

Keywords: nun, congregation, Second Vatican Council, reform, Congregation for the Doctrine of the Faith, vocation

\section{Historical Context}

$\prod_{\text {progress } 20^{\text {th }} \text { century turned out to be a time of accelerated civilization }}$ Technological progress included not only Europe and America, but gradually began to spill over to the whole world, thus contributing

\footnotetext{
${ }^{1}$ This article is a translation of the article originally published in Polish: Michał Chaberek, "CMSWR kontra LCWR. O kryzysie i odnowie żeńskiego życia konsekrowanego w USA," Collectanea Theologica 88 (2018) no. 3, 115-135. Translated from Polish by Maciej Górnicki.
} 
to a new phenomenon of globalisation. Faced with the changing circumstances of life, the level of prosperity, the level of education and new technical achievements, religious life encountered challenges previously unknown in history. Not only did life change on a practical level (new means of transportation such as cars and planes, new appliances such as washing machines and refrigerators), but above all the mentality of the new generations evolved.

Religious sisters obviously came from society and even if they were mainly recruited from more traditional families, their understanding of the world was also different from that of the Middle Ages or the $19^{\text {th }}$ century. Even before the sexual revolution, the understanding of freedom had changed, and from an external focus on the objective good it was increasingly understood as a discernment of the individual good in the context of human community. This evolution was undoubtedly part of the development of a democratic social system. This, of course, influenced the understanding of obedience in religious orders. ${ }^{2}$ The increasingly prosperous life of Western societies meant that candidates for religious life were not accustomed to the harsh conditions so well known to their parents. Eventually, the collapse of the moral principles of the bourgeois society, and later the sexual revolution, set the vow of chastity in ever clearer opposition to the dominant culture. The far-reaching social changes were a fact. For this reason, certain elements of religious life in highly developed countries already in the mid-twentieth century demanded modernization.

In the face of the changes taking place the higher Church circles recognized the need for reform. ${ }^{3}$ Already in 1950, when Pope Pius XII defined the general principles for the female orders, he called for a careful and prudent (caute prudenterque) adjustment (accomodatio) of those elements of the religious life which were

${ }^{2}$ An insightful analysis of the evolution of the understanding of the vow of obedience is proposed by J. Schaefer in the book The Evolution of a Vow: Obedience as Decision Making in Communion, Lit Verlag: Berlin 2008, especially pp. 14-20.

${ }^{3}$ Many bishops and cardinals began to speak about the reform of the female orders. One example is a book by Belgian Cardinal L.J. Suenens, The Nun in the World [Siostra w świecie], Revised Edition, The Newman Press: Westminster, MD 1963. 
only of historical importance, which were created at a certain time and either ceased to fulfil their role or even began to hinder the performance of new tasks in the orders. ${ }^{4}$ Pius XII did not limit himself to writing documents. He also called to Rome the First Congress of the States of Perfection, attended by religious superiors from all over the world. As a response to the papal call for communication between religious orders and for renewal, first the Sisters Formation Conference was formed in the United States and then, in 1956, the Conference of Major Religious Superiors of Women's Institutes (CMSW) was established. Its primary task was to promote the spiritual good of the American sisters, to increase the efficiency of their ministry, and to stimulate closer cooperation among all consecrated person in the United States as well as with bishops, priests and Catholic associations. For fifteen years, the CMSW has fulfilled these tasks by organizing regional and national meetings, setting up permanent commissions for: Latin America, catechesis, health and finances. ${ }^{5} \mathrm{~A}$ similar organization was established by the superiors of the male orders. Both received canonical status. However, no significant reforms took place. On the one hand, the sisters were too busy with apostolic work to undertake any serious reflection on their lives; on the other hand, bishops and pastors also valued the status quo, according to which active orders

\footnotetext{
${ }^{4}$ Pius XII distinguished three components of the religious formula, namely: the proper and necessary elements of the female monastic life, then the elements that are not necessary but auxiliary and complementary, and finally those that are neither necessary nor complementary, but only external and historical. The reform, according to the Pope, was to be applied to this third category. See Pius XII, Apostolic Constitution Sponsa Christi. On the promotion of holy female institutes, http://www.vatican.va/content/pius-xii/la/apost_constitutions/documents/hf_p-xii_ apc_19501121_sponsa-christi.html (02.07.2018). Ann Carey defines the nature of the reforms called for by Pius XII on the example of some religious habits, which, because of their cut, posed a risk of accident when operating new devices such as washing machines. Some headgear limited visibility in such a way that in some states in the USA no driver's license was issued to sisters. Such inconveniences had to be removed in accordance with the Pius XII reform. See: A. Carey, Lecture: Religious Life: In Crisis or at the Crossroads? https://www.youtube.com/watch? $\mathrm{v}=\mathrm{r} \_$nihMHrKnE; 11:20-12:15; (02.07.2018).

${ }^{5} \mathrm{M}$. Clark, Two groups, two paths for US women religious, in "National Catholic Reporter," May 26, 2012, https://www.ncronline.org/news/global-sisters-report/ two-groups-two-paths-us-women-religious (04.07.2018).
} 
provided much-needed hands for work in growing Catholic institutions.

The 1950s and 1960s were a golden time not only for the economy. In addition to steadily growing macroeconomic indicators, American Catholicism enjoyed the growth of female religious congregations. In 1930 there were 135 thousand sisters, the number reached its maximum in 1965, exceeding 180 thousand. More than three hundred orders and religious congregations served a significant part of the system of parish schools, Catholic medical care and social assistance. Almost every American Catholic has experienced religious formation from the sisters at some stage. Religious sisters were the driving force behind American Catholic culture and the "working class" of the Church.

However, over the next fifty years, the number of sisters decreased by 130 thousand (reaching 50 thousand in 2014) and the number of religious orders shrank to just over two hundred. This means that more than one hundred congregations have completely disappeared from the USA and the number of sisters has decreased by more than $70 \%$ while the number of Catholics has increased by more than $30 \% .{ }^{6}$ Catholic education was particularly severely affected - from over 100 hundred thousand sisters teaching in 1965 there were about 4 thousand sisters in 2012. During this period more than half of the Catholic primary and secondary schools were closed down, while the number of Catholic hospitals decreased by $23 \%$.

The obvious question comes to mind, how did this happen? How is it possible that the flourishing vocations and works of community over a generation have lost so many members and in many cases have come to the brink of physical survival? In 2012 the average age of the sisters reached 74 years. ${ }^{7}$

\footnotetext{
${ }^{6}$ Part of the statistics is given after Ann Carey, Sisters in Crisis: The Tragic Unraveling of Women's Religious Communities, Our Sunday Visitor Publishing Division 1997, and second edition: Ignatius Press 2013. Part is given after Wikipedia: https://en.wikipedia.org/wiki/Catholic_sisters_and_nuns_in_the_Unit ed_States (02.07.2018).

${ }^{7}$ See: The Vanishing of the Nuns, in New York Times, https://www.nytimes.com/ 2012/12/02/booming/the-vanishing-of-the-nuns.html (02.07.2018).
} 


\section{Post-Conciliar Crisis}

As is often the case with social phenomena there is no single or unambiguous answer to the question about the reasons. In fact, the rapid decline of American nuns cannot be considered as a social phenomenon alone. Undoubtedly, this crisis also has a spiritual dimension, which is not strictly the subject of this study. In further analysis we will therefore focus on the facts that partially answer the question.

The year 1965 marked the conclusion of the Second Vatican Council and many new developments in the Church. In the document Perfectae caritatis, ${ }^{8}$ the Council gave the general principles for the renewal of religious life, which were then to be expanded in ecclesiastical documents of lower rank. ${ }^{9}$ The activities of the Vatican, although carried out in close contact with religious superiors, met with reactionary actions for the autonomy of sisters in the USA. Already in 1969 the National Coalition of American Nuns (NCAN) and a year later the National Assembly of Religious Women (NARW) were established. Both organizations were modelled on secular feminist movements, were grass roots initiatives and aimed to develop cooperation between sisters and promote social justice and equality of women. ${ }^{10}$ Still at the time of the Council, the superiors gathered at the CMSW began to explore possible sources and directions of renewal. The fruit of this research was a book published in 1965, The Changing Sister. The book consisted of essays written by nine sisters who presented their vision of renewal. The book had a major impact on a survey conducted by the CMSW two years later among almost all active sisters

${ }^{8}$ See: Perfectae caritatis, p. 1. http://www.vatican.va/archive/hist_councils/ii_ vatican_council/documents/vat-ii_decree_19651028_perfectae-caritatis_lt.html (02.07.2018).

${ }^{9}$ Already in 1966, the Motu proprio Ecclesiae sanctae of Pope Paul VI was published. The second chapter gave more detailed rules for the renewal of religious life. In 1969, further documents appeared: Renovationis causam (on the renewal of formation) and Venite seorsum (on the renewal of the contemplative orders)

10 The NARW Group collected information about the Leadership Conference of Women Religious, as well as about extreme organizations such as NARW: Women's Ordination Conference, United Farm Workers of America, Dignity, and Catholics Act for ERA (the Equal Rights Amendment). 
(157 thousand). The so-called "Sisters' Survey" was a multi-point questionnaire that was intended to set out the directions of the reforms proposed by the sisters themselves. Critics of the survey indicated that it was also a tool of indoctrination, which was intended to introduce radical ideas into the cloisters.

Crucial, however, was the year 1970, when, under the influence of the "Sisters' Survey," the statutes of the CMSW were changed. The Conference began accepting members who were not superiors and changed its name to the Leadership Conference of Women Religious (LCWR). Although the Conferences of Superiors are dependent on the Congregation for Religious Affairs, Church authorities were not asked for permission to make the changes, but only informed after the fact. As a result, the LCWR became a new institution, modelled on secular corporations, recognizing its independence from the Vatican and managed by a group of activist sisters. The group's goal was not only to reform female religious orders, but to influence Church discipline and society as a whole.

At the same time, an alternative small organisation, the Consortium Perfectae Caritatis, has emerged from the LCWR, and it expressed concern that the LCWR was moving away from the teaching of the Church. ${ }^{11}$ The first formal meeting of the Consortium took place on 2 December 1970. In addition to about 60 sisters, one cardinal, two bishops and several priests were present. About three other bishops sent their greetings. Bishop Fulton J. Sheen was present at the first General Assembly in 1971. The sisters then defined the essential elements of religious life based on the conciliar document Perfectae Caritatis. Apart from the pursuit of holiness through the vows and the importance of the religious habit, obedience, communication and collaboration with the Pope, the Bishops and the Congregation for Religious were also prominent. ${ }^{12}$ In the 1970s, the Consortium remained the only association of religious sisters that clearly advocated obedience to the teaching of

\footnotetext{
${ }^{11}$ M. Clark, op. cit.

12 The name "Congregation for Religious" was in force since 1908. After the 2nd Vatican Council II, Paul VI changed the name to "Congregation for Religious and Secular Institutes." In 1988 John Paul II changed the name to "Congregation for Institutes of Consecrated Life and Societies of Apostolic Life." For the sake of clarity, in this article I consistently use only the first name.
} 
the Church. However, until 1992, the CMSW-LCWR remained the only organization recognized by the Vatican as the body officially representing American sisters in Church structures and law. The Consortium received only the decretum laudis from the Congregation for Religious, a letter of commendation. Similarly, many American bishops phrased their acknowledgement for this group, while many others, although sympathetic to the attitude of this minority group, have not expressed their opinion in order not to deepen the already sharp division among the sisters. ${ }^{13}$ The Church authorities encouraged the Consortium's superiors to remain members of the LCWR as well. However, this did not happen and the sisters of the Consortium gradually left the LCWR. Between 1971 and 1975, at the request of the Vatican, the two groups met several times (including once in Rome, where the Prefect of the Congregation for Religious led the meeting) to reach an agreement. However, the meetings led to a common position on only two issues: First, that the formation of the Consortium did not deepen the division, because it had existed even before the formation of the organization. Secondly, that the two groups had very different visions of religious life, which could not be harmonized. The dialogue was suspended until 1989.

In 1971 Paul VI announced the Exhortation Evangelica tesitficatio. The Pope made an initial assessment of the recent reforms of the religious orders, and once again called for the reform of the peripheral elements and the preservation of the essential ones. ${ }^{14}$ Three years later, the LCWR responded critically to Paul VI's exhortation by publishing the document Widening the Dialogue, in which the Conference presented its own vision of further reform. Widening the Dialogue was a book-collection of essays in which the authors questioned the papal authorship of the

13 A. Carey, Sisters in Crisis: The Tragic Unraveling of Women's Religious Communities, second edition, San Francisco: Ignatius Press 2013, Kindle edition, loc. 2096.

${ }^{14}$ Paul VI, Evangelica testificatio, http://www.zyciezakonne.pl/dokumenty/kosciol /pawel-vi/pawel-vi-adhortacje/adhortacja-apostolska-evangelica-testificatio-wska zania-na-temat-odnowy-zycia-zakonnego-wedlug-nauki-soboru-watykanskiego-ii20431/ (05.07.2018). 
document, called for discussion about its theses and accused the Pope of taking a step back to the pre-conciliar era. ${ }^{15}$

In the 1970s, most congregations and religious orders radically changed their constitutions and customs, often violating even the essential elements. As Ann Carey writes: "Some communities have given their members total freedom to decide where and how they will pray, live, what work they will do, what hours they will follow and how they will dress - a freedom that has led to exaggeration, such as sisters in mini skirts, smoking, drinking and going out with a boyfriend. ${ }^{16}$ The new constitutions of one of the congregations included provisions for the joint management of the congregation, because "the Spirit speaks through all members, not only superiors," stating that the time and frequency of common prayers are to be determined by local communities, and that "each member may wear whatever she wishes with regard to clothing, veil and external sign of consecration." ${ }^{17}$ In many cases, the new constitutions, established ad experimentum, did not have the appropriate permissions from the Holy See for their temporary validity, even though this was required by the Church law. As early as 1967, Father Bernard Ransing, a member of the Congregation for Religious and assistant to the CMSW, warned at the CMSW assembly that "a considerable number of unapproved experiments have been initiated [recently], misunderstanding or misinterpreting the intentions of the Holy See [...]." ${ }^{18}$ In the same year, Cardinal Egidio Vagnozzi, Apostolic Delegate to the United States, spoke with Sister Mary L. Tobin, President of the CMSW, about the fact that non-approved experts should not be invited to teach the sisters about the conciliar reforms.

In 1972, the Congregation for Religious admonished the sisters twice - the first document Experimenta circa reminded that a completely democratic model of exercising power in religious orders is unacceptable, because the superior must have personal authority. Then the Congregation sent a letter to the mothers

\footnotetext{
15 A. Carey, op. cit., loc. 741.

16 Ibid., loc. 573.

17 Ibid., loc. 594.

18 B. Ransing, a letter to the CMSW assembly, in Proceedings of the Annual Assembly 1967, Washington D.C.: Conference of Major Religious Superiors of Women's Institutes of the USA, 1968, p. 150.
} 
superiors indicating the recurring problems in the reforms of various congregations and reminding about the necessity of consulting the Holy See about the changes. During the 1970s, the direction of changes in many congregations was not modified under the guidance of the Holy See and many congregations made it clear that they had no intention to submit.

\section{LCWR versus John Paul II}

In 1979 John Paul II made his first apostolic pilgrimage to the United States. While welcoming the Pope to the National Shrine, the church of the Immaculate Conception, the Superior of the LCWR, Sr. Theresa Kane, called on the Pope to allow women to perform all types of pastoral functions. Although Kane did not mention the priesthood of women, it was clear that this was precisely what her request was about. Kane's speech earned the applause of part of the congregation, which put John Paul II in a clearly uncomfortable situation. ${ }^{19}$ However, this incident was just a media manifestation of the relations between the Holy See and the LCWR, which had existed since the late 1960s.

In the early 1980s, John Paul II asked the Congregation for Religious to evaluate the state of reforms. In justification of his request, the Pope wrote to the American bishops that he asked for an evaluation because of the unprecedented number of departures from the priesthood and religious life and the dramatic decrease in the number of vocations. The document issued by the Congregation, entitled The Essential Elements in the Church's Teaching of Religious Life with regard to active institutes, ${ }^{20}$ did not introduce any novelties, but merely reminded and explained the laws

\footnotetext{
${ }^{19}$ Ample fragments of the speech available at the archive of The New York Times: https://www.nytimes.com/1979/10/08/archives/excerpts-from-nuns-greeting-andpopes-remarks-greeting-by-nun.html (04.07.2018). A short document devoted to Sr. Kane contains a video from this speech: https://www.youtube.com/watch?v=ua MWC3qZ6TI\&t=35s; 1:00-1:20 (04.07.2018).

${ }^{20}$ Essential Elements in the Church's Teaching on Religious Life as Applied to Institutes Dedicated to Works of the Apostolate, Rome, 23 May1983, http://www. vatican.va/roman_curia/congregations/ccscrlife/documents/rc_con_ccscrlife_doc_ 31051983_magisterium-on-religious-life_en.html (04.07.2018).
} 
governing religious life and signalled the end of the "period of experimentation" called for by the 1966 document Ecclesiae sanctae. Some sisters officially responded with anger and disapproval of the papal study of consecrated life, considering the initiative to be an offensive inquiry that showed the American sisters in a bad light. Although the document was based on the conciliar texts, some sisters accused the Vatican of trying to reverse the Council reforms. One of the Loreto sisters, Ann Patrick Ware, wrote in 1985 about "ominous signs hanging in the air" that would lead to "the reversal of the renewal work carried out by female religious communities." ${ }^{21}$ Similar remarks were published by sisters and journalists, former sisters, such as Dorothy Vidulich and Anita Caspary. At the 1983 LCWR Assembly, forty-three members publicly rejected the document as foreign to the experience of the American sisters. In their opinion, the document offends "the American cultural sensitivity - the voice of the community is clearly absent from the document, its approach is ahistorical, detached from experience, its aim is to suppress what Rome sees as a rebellion, it is an anonymous document, created in secret, its fuzzy ambiguous legal authority opens the door to uncontrolled administrative abuse." 22

Of course, not all the sisters rejected the Essential Elements. For example, Sister Claudia Honsberger of the Servants of the Immaculate Heart of Mary published a long defence of the document. Sister Honsberger had previously held the position of president of one of the regions of the CMSW, but she distanced herself from the official position of the Conference several times. In her opinion, the religious communities did not take a close look at the conciliar teaching, which caused many distortions in its understanding, and the current criticism of the Essential Elements results from the fact that many religious persons adopted a lifestyle completely different from that described in the document.

\footnotetext{
${ }^{21}$ A.P. Ware, Introduction, in Midwives of the Future, Kansas City: Leaven Press 1985 , p. 3, quote after A. Carey, op. cit. loc. 805.

${ }^{22}$ Quote after A. Carey, op. cit. loc. 824. Although 43 sisters from over a thousand members is not much, it shows the general spirit of this organization, which also failed to generate any official opposition to this initiative.
} 
In 1983, John Paul II called on the American bishops to carry out a broad audit of the female orders in order to determine the reasons for the decline in vocations. The document Essential Elements was to serve as a point of reference during discussions with the sisters. The Pope put San Francisco Archbishop John Quinn at the head of the bishops' commission.

At the same time, a number of scandals involving individual nuns broke. The case of Sister Agnes Mary Mansour from the Congregation of the Sisters of Mercy got a lot of publicity. Mansour was the head of the welfare office of the State of Michigan, which was involved in financing abortion. The Archbishop of Detroit, Edmund Szoka, called on Sister Mansour to resign from this function, and when this did not work he asked the Vatican for help. The Congregation for Religious obliged the sister by virtue of obedience to withdraw from the office but the sister refused and left the order. Dissatisfaction with the attitude of the Church authorities was expressed by various organizations of nuns, including NARW and NCAN.

Another case of outright disobedience was that of Sr. Arlene Violet, also from the Sisters of Mercy congregation, who applied for the post of Attorney General in Rhode Island. She did not have the consent of her superiors, and in addition, the new Code of Canon Law forbade consecrated persons from performing state functions. However, Violet decided to leave her order to become an attorney. ${ }^{23}$ One of the most famous incidents was also the support of 26 sisters for an appeal for free access to abortion, which was published in the New York Times as a private advertisement. ${ }^{24}$ The Vatican called on the sisters to withdraw their support under threat of removal from

\footnotetext{
${ }^{23}$ See: F. Butterfield, "Rhode Island Nun Quits her Order to Run for Attorney General," in New York Times, 30 stycznia 1984, p. 14, https://www.nytimes.com/ 1984/01/20/us/rhode-island-nun-quits-her-order-to-run-for-attorney-general.html (05.07.2018).

${ }^{24}$ In total, the appeal was signed by about 100 people, including two nuns, one diocesan priest and one religious. See: K.A. Briggs, "Vatican Threat on the Abortion Ad Went to Signers," in New York Times, 7 October 1984, p. 16, https://www.nytimes.com/1984/12/19/us/vatican-threat-on-abortion-ad-went-tosigners.html (05.07.2018).
} 
their orders. Initially, all the sisters refused to obey, but after some time, only two persisted and left the order.

The Quinn Commission met with resistance from the sisters right from the beginning. During the Commission's first meeting with the LCWR, the LCWR President Sr. Helen Flaherty stated that most major superiors disagree with the Vatican position. "We see the decline [of the religious orders] as a positive sign," Flaherty said, "because it leads to greater participation of the laity in the ministry of the Church [...] It is not about numbers." ${ }^{25}$ The NARW coordinator, Sr. Marjorie Tuite, compared the Commission to a "witch hunt." 26 Other superiors expressed similar angry opinions.

The sisters' meetings with the bishops eventually took place, although in many cases no difficult questions were asked and the general spirit of these meetings was that the sisters were instructed to focus on the "achievements" and "positive aspects" of the current situation. In many cases, only superiors or activists from the LCWR met with bishops and used the opportunity to instruct Rome about the new American vision of religious life. Eventually, the Quinn Commission issued a 52-page report which, among other things, described the possible causes of the vocation crisis. Unfortunately, they were mainly found in cultural and social factors. The report was very laconic about the religious orders themselves and their reforms, the problem of divisions between sisters and the conflict with the Vatican. Finally, the Commission stated that the three years of work led it to the conclusion that "generally speaking, religious life in the United States is in good shape."27

The Quinn Commission's work was finally summarized in 1989 at a meeting of American bishops with the Pope at the Vatican. The papal representatives gently made it clear to the bishops that they were not entirely satisfied with the work of the Commission. And, in turn, John Paul II sent a letter in which he pointed out that the bishops had done only two of the three parts of the task they had been asked to do - listening and dialogue - but had not proceeded

${ }^{25}$ Quote after A. Carey, op. cit. loc. 4166.

${ }^{26}$ Ibid., loc. 4173.

${ }^{27}$ Pontifical Commission on Religious Life, "Report to U.S. Bishops on Religious Life and the Decline on Vocations," in Origins, Dec. 4, 1986, p. 470. 
with the third part, the special pastoral tasks that were meant to inform and instruct the sisters about the Catholic understanding of consecrated life.

The conflict between the Holy See and the LCWR calmed down for the next twenty years until the Congregation for the Doctrine of the Faith attempted a doctrinal evaluation of the LCWR activities. During this time the number of sisters continued to shrink at an alarming rate. The Synod on the Consecrated Life (1994) and the subsequent exhortation Vita Consecrata (1996) did not provoke too many negative reactions. This was probably because the exhortation was more theological in nature and did not contain the expected attack on the abuses observed in the USA.

\section{The Long-Awaited Alternative - CMSWR}

On the wave of post-conciliar changes in 1976, another organization was established whose aim was to support consecrated life. This was an organization established on the initiative of a group of bishops, called the Institute on Religious Life (IRL). The IRL brought together priests, monks, nuns as well as laity, but it also had a separate body for religious superiors - the Forum of Major Superiors. From the beginning the organization was very active in the field of spirituality, as well as psychology and other aspects of consecrated life. Most of the members of the Consortium Perfectae Caritatis gradually also joined the IRL.

As I have already mentioned, in 1989 John Paul II gathered 35 American bishops in the Vatican to discuss the deepening crisis in female congregations. The key speech was that of Cardinal James Hickey, who said, among other things, that the LCWR was the only official channel of contact between the Vatican and the sisters, although this organization did not represent all the nuns. Soon the Pope made it clear that he heard the sisters' voice and established Cardinal Hickey as the official liaison between the Vatican and the sisters not affiliated in the LCWR. At the same time, he asked the cardinal to promote dialogue between the sisters from both groups. Several meetings of the Consortium Perfectae Caritatis with the LCWR over the course of the years 1989 and 1990 did not bring any new results. At the last meeting, the President of the LCWR, Sister 
Doris Gottemoeller, stated that the organization no longer had the patience to continue the dialogue, either with the Consortium or with the IRL, and that if the sisters from the Consortium want to go on with the dialogue, they should simply enrol in the LCWR. ${ }^{28}$

As a consequence of the failure of the dialogue with the LCWR, the idea of merging the Consortium with the Forum of Major Superiors being a part of the IRL emerged, but during the talks it soon became clear that the major superiors of female religious orders need a separate organization which should be officially recognized by the Vatican. In January 1992, Cardinal Hickey presented the proposal to the Pope, who supported the project. The LCWR was officially informed of the creation of the second conference of major superiors, which would be recognized by the Vatican as an official body representing the sisters. The dissatisfied board of the LCWR quickly went to the Vatican to discuss the initiative with the Prefect of the Congregation for Religious, Cardinal Somalo. At the same time, a book entitled Transformation of American Catholic Sisters was published, in which two former directors of the LCWR told the story of the organization - how it was transformed in 1970 and what methods of operation accompanied this process. The supporters of the new alternative organization made sure that the book was well publicized in Rome. As a result, in June of that year the Congregation for Religious established the Council of Major Superiors of Women Religious (CMSWR), which had the same canonical status as the LCWR. Following the decision of the Vatican the Consortium and the Forum of Major Superiors were dissolved. 84 Superiors joined the new organization, representing only about $10 \%$ of the perpetually professed sisters, but at the same time - the majority of the sisters in formation. In response, the LCWR together with the Conference of Major Superiors of Men (MCSM) sent a joint protest to the Vatican stating that establishing the new organization did not serve unity and would open the old wounds. However, the existence of an alternative organization on an equal canonical basis was already a fact.

In 2012 the LCWR had 1500 members representing about $80 \%$ of the nuns, while the CMSWR gathered 108 religious congregations.

${ }^{28}$ A. Carey, op. cit. loc. 2281-2287. 
Both organizations published books which constituted some kind of their working programs. The CMSWR published in 2009 The Foundations of Religious Life: Revisiting the Vision, which includes essays on religious vows, spousal bond, community and evangelization mission. This programmatic publication of the CMSWR is an example of a modern understanding of religious life in connection with the centuries-old tradition of the Church. ${ }^{29}$ Conversely, among the LCWR's publications one can find the Mentoring Leadership Manual as well as various studies concerning leadership functions for women in the Church.

\section{Apostolic Visitation of the Sisters and a Doctrinal Assessment of the LCWR}

In January 2009, it was announced that the Congregation for Religious Affairs would conduct an apostolic visitation to all active female congregations in the USA. For this purpose, 72 persons were appointed, all of them American, consecrated persons, mostly women. The group was headed by Mother Mary Clare Millea of the Congregation of Catholic Apostles of the Sacred Heart of Jesus. Three months later it was revealed that the Congregation for the Doctrine of the Faith is working on a doctrinal evaluation of the LCWR. On hearing about the visitation, the LCWR reacted by saying that "it is a surprise for the organization and its purpose and effects on the lives of American nuns are unclear." 30 The CMSWR, in turn, issued a statement which stated, among other things, that "The Council welcomes the Inspectors and asks its members to pray for this venture and to cooperate in all necessary ways so that the visit will be fruitful for all nuns in the US for the good of the Church." 31 Soon the LCWR sisters began to sabotage the activities of the Visitation Commission. Sister Sandra Schneiders, for example, in a private e-mail that was later published in the press, said that the visit was "a hostile move and the conclusions are pre-

${ }^{29}$ Council of Major Superiors of Women Religious, The Foundations of Religious Life: Revisiting the Vision, Notre Dame (ID): Ave Maria Press 2009.

${ }^{30}$ Quote after A. Carey, op. cit. loc. 5357.

31 Ibid., 5363. 
conceived; its purpose is to intimidate. [...] Although we can't stop them from asking, we can welcome them politely and nicely, just as we should welcome uninvited guests, in the parlour, without showing them around the house." 32 Other LCWR sisters spoke in a similar tone. Nevertheless, Sr. Mary Clare started the talks. As the work progressed, they were increasingly criticised by persons associated with the LCWR, but the overall experience of the sisters was positive, the talks went smoothly, and there were no complaints about the way the Commission acted. This also caused the former president of the LCWR, Sr. Marlene Weisenbeck, to admit in 2010 that "there was anger at first, but as people had good experiences, attitudes changed." ${ }^{33}$ In early 2012, Sr. Mary Clare sent the Congregation for Religious Affairs a visitation report and all the sisters' individual written reports. In total, members of about a hundred religious orders representing a quarter of the American sisters were interviewed.

In April 2009, the Congregation for the Doctrine of the Faith announced that it would carry out a doctrinal assessment of theology promoted by the LCWR. In a letter to the LCWR, Cardinal William Levada, Prefect of the Congregation for the Doctrine of the Faith (hereinafter CDF), reminded the sisters that already in 2001 the Congregation had informed the LCWR about the doctrinal errors present in their publications. However, since the LCWR did not rectify the teaching, the Congregation began a formal evaluation process. This ecclesiastical initiative also produced a negative reaction from the LCWR. The sisters, although they did not attack the CDF directly, began to build a front for broad media and social support, presenting themselves as victims of male hierarchy. At the same time, President Obama's administration implemented a new health care system that forced all private entities to sponsor abortion and contraception. The LCWR supported the new regulations, thus standing directly against the official position of the American

${ }^{32}$ S. Schneiders, "We Have Given Birth to a New Form of Religious Life," in National Catholic Reporter, 27 February 2009.

${ }^{33}$ Weisenbeck also said that she heard positive reactions and that people learned something about themselves through the visit. „The Mood Has Been Changing," in National Catholic Reporter, https://www.ncronline.org/news/mood-has-beenchanging (06.07.2018). 
Episcopate. The presidents of the LCWR did not withdraw from this decision even after a conversation with Cardinal Levada in the Vatican.

In April 2012, the CDF issued a document entitled The Doctrinal Assessment of the LCWR, ${ }^{34}$ in which it assessed that the LCWR documents "manifest problematic statements and serious theological, even doctrinal errors." The CDF pointed out that the official statements of the LCWR members distort the role of Jesus in the salvation of the world, undermine the revealed doctrine concerning the Trinity and the inspiration of the Holy Scriptures, reject the authority of the Church, promote unacceptable views on the Eucharist, the nature of religious life, the ordination of women, human sexuality and the pastoral care of homosexual people. The document gave as an example the speech of Sr. Laurie Brink, who in 2007 said that some religious orders "have grown beyond the boundaries of institutional religion, ... beyond religious titles, institutional restrictions, Church authorities no longer fit into such congregations." Sister Brink asked rhetorically: "Who will say that going beyond Christ is not really an entrance into the very heart of God?"35

As a solution, the CDF in its document ordered the appointment of a bishop delegate who, together with two other bishops, would carry out the reform of the LCWR's statutes, programmes and activities within a period not exceeding five years. Peter Sartain, Archbishop of the Diocese of Seattle, was elected the bishop delegate of the Congregation. Several months later, the LCWR responded to the $\mathrm{CDF}$ document stating that the accusations were unfounded, that the assessment process was unclear, that the sanctions were disproportionate to the problems raised, and that the document caused scandal and even greater division within the Church. At the same time, the LCWR continued to promote leftist social policy and heterodoxical theological concepts. For example, in August 2012, Barbara Marx Hubbard, an agnostic promoting the

\footnotetext{
${ }^{34}$ http://www.vatican.va/roman_curia/congregations/cfaith/documents/rc_con_cfa ith_doc_20120418_assessment-lcwr_en.html (05.07.2018).

${ }^{35}$ Quote after G. Weigel, Evangelical Catholicism, New York: Basic Books 2013, p. 184.
} 
concept of "conscious evolution" in the spirit of Teilhard de Chardin and the New Age, was the main speaker invited to the gathering of the LCWR. In 2014, the LCWR awarded the annual prize to sister Elizabeth Johnson, whose book about God was found erroneous by a committee of the American Episcopate.

In April 2014, Cardinal Gerhard Müller, the new prefect of the CDF, together with Archbishop Sartain, sent a message to the LCWR in which they demanded that the New Age practices and beliefs be abandoned under the threat of the organization being deprived of its canonical status. ${ }^{36}$ However, on April 16, 2015, the activities of Archbishop Sartain and the CDF came to an end. After the meeting of the LCWR representatives with Pope Francis, a joint final report of the LCWR and the CDF was issued, which stated that the joint work in response to the CDF (2012) call had "borne much fruit." "The governing body of the LCWR will remain faithful to its key role in serving the members and tasks of the Conference. It will continue to lead the testimony of the religious life of the LCWR and strengthen its foundation in Christ and the Church community. ${ }^{37}$

In this way, as George Weigel concluded, "any serious reform of the female religious communities according to the guidelines of the Second Vatican Council and the Vita Consecrata will have to be carried out at the level of individual congregations. Fortunately for the supporters of profound reform, it is precisely those congregations that will most likely have members in the mid- $21^{\text {st }}$ century, after the LCWR religious orders have disappeared due to their own intrinsic incredibility." 38 According to a survey conducted

36 See: H. White, "U.S. nuns must give up New Age ideas or lose Vatican recognition: CDF head to LCWR nuns," https://www.lifesitenews.com/news/u.s.nuns-must-give-up-new-age-ideas-or-lose-vatican-recognition-cdf-head-t (06.07.2018).

37 Joint Final Report on the Doctrinal Assessment of the Leadership Conference of Women Religious (LCWR) by the Congregation for the Doctrine of the Faith $(C D F), 16.04 .2015$, https://press.vatican.va/content/salastampa/it/bollettino/pubbli co/2015/04/16/0278/00618.html (06.07.2018).

${ }^{38}$ G. Weigel, op. cit. p. 186. For the sake of accuracy, it should be added that Weigel expressed this opinion in 2013 when Archbishop J. Tobin, who criticized the work of the KNW and Archbishop Sartain, became Prefect of the Congregation for the Religious. Tobin was soon removed from office. Weigel's assessment became even more pertinent after Pope Francis concluded the work of the SCW two years later. 
in 2016, 165 postulants joined CMWSR congregation in that one year and 137 sisters began their novitiate. ${ }^{39}$ With an average age of 58 (20 years less than the LCWR) and steady number of vocations, sisters can look to the future with optimism.

\section{Summary and Conclusions}

The difference between the LCWR and the CMSWR does not only concern some religious practices or pastoral vision. In fact, the two organisations represent two completely different world views and even, as shown in the examples, two belief systems. When we look at the LCWR website, in addition to many elderly women enjoying themselves, we will be particularly struck by the press releases edited by the organisation. These include attacks on President Trump's administration, the policy of the Republican Party, occasional information about the sale of another property and much concern for illegal immigrants, the poor and women. Any references to religion or the Church appear only in the promotion of ambiguous books on the borderline of psychology, New Age and spirituality. It seems that the biggest problem of the LCWR is not so much the position on specific political issues as the extreme politicization of the organization, its revolutionary and extremely ideological spirit. The vertical dimension, which is the very centre of religious and Christian life, has been replaced by the horizontal dimension. It is therefore not surprising that the orders led by the LCWR have lost the power of attraction for the young. After all, if a young woman wants to get involved in the fight for equality or social justice, she is much more likely to join one of the political parties or NGOs. They fulfil these tasks much more effectively than a nuns' conference. Religious orders draw people who are interested in giving their lives to Jesus and entrusting themselves to the service of the Church. An organization which openly rejects the authority of the Church cannot attract such people. That is why nowadays the postulancies and novitiates are full of candidates in religious orders such as Dominican Sisters of St. Cecilia of Nashville, Dominican

39 http://cmswr.org/wp-content/uploads/RELEASE-2017-Demographic-SurveyReport.pdf (08.07.2018). 
Sisters of Our Lady Mother of the Eucharist of Ann Arbor (MI), Religious Sisters of Mercy of Alma (MI), Carmelite Sisters of the Sacred Heart of Los Angeles, Sisters of Life of New York, and Sisters of Missionary Love. These and many other congregations affiliated to CMWSR have taken up the call for the renewal of consecrated life made by the Second Vatican Council in a clear and responsible manner. When we look at the CMWSR website, we shall see young sisters in their habits and many materials concerning religious spirituality, vocation and the life of prayer. All this indicates that the future belongs to a minority faithful to Christ. 